\title{
EPIPHYTIC MOSSES IN THE CENTRE OF TIRANA CITY (ALBANIA)
}

\author{
Jani MARKA* and Imelda ZALOShNJA \\ Department of Biology, Faculty of Natural Sciences, Tirana University, \\ Blvd.Zogu I, Tirana, Albania; *jani.marka@fshn.edu.al
}

Marka, J. \& Zaloshnja, I. (2017): Epiphytic mosses in the centre of Tirana city (Albania). - Studia bot. hung. 48(1): 51-65.

\begin{abstract}
This study is aiming to give a general overview about epiphytic moss communities of trees in the main streets of Tirana's city centre and its adjacent park. Altogether 145 trees were investigated for epiphytic mosses during the spring of 2016. Altogether 553 moss samples were collected resulting in a total of 40 moss taxa, 19 taxa for strictly urban area and 39 for park area, with 18 taxa being in common for both communities. For the strictly urban area the five most common species were Orthotrichum diaphanum, Syntrichia papillosa, Fabronia pusilla, Homalothecium sericeum and Syntrichia laevipila. From the other side, the five most common species of the Park area were Hypnum cupressiforme, Homalothecium sericeum, Syntrichia papillosa, S. laevipila and Leucodon sciuroides. The values of biodiversity indices were higher for the park area, and the similarity between these two communities was of average degree. Among the epiphytic mosses recorded some are resistant to air pollution and others are sensitive to it. The question if the differences seen between the two communities are only a consequence of microclimatic conditions remains open, as a long term monitoring of biodiversity dynamics will be needed on the one hand and a standardised method to check for correlations between biological parameters and chemical-physical parameters on the other hand.
\end{abstract}

Key words: urban flora, biodiversity, air pollution, Albania

\section{INTRODUCTION}

In Europe there are plenty of studies of urban bryofloras. In the study of the Belgrade bryoflora (SABOVLJEVIĆ and GRDović 2009) abundant literature for European cities is given where studies of urban bryoflora are conducted, such as: Berlin and Brandenburg (SCHAEPE 1986, BENKERT et al. 1995), Brussels (VANDerpoorten 1997), Vienna (HohenWAllner and Zechmeister 2001a, $b$, Zechmeister et al. 2001, HoHenwallner 2000a, b), in many urban areas of Spain (Ballesteros Segura and Ron 1985, Casas and Saiz 1982, Esteve et al. 1977, Fiol 1983, Ron et al. 1987, Heras and Soria 1990, LARA and MAZimpaka 1989, LARA et al. 1991, MAZimpakA et al. 1988, 1993, Soria and Ron 1990, 1995, Soria et al. 1992, VICENTE et al. 1986, RAMS et al. 2000), Portugal (Bento-Pereira and Sergio 1983, Sergio 1981, Sergio and Bento- 
Pereira 1981), and Italy (Carcano 1989, Cortini-Pedrotti 1989, Aleffi 1991, Aleffi and Taruschio 1996, Dia and Not 1991, Mazimpaka 2006, Lo GiUdice 1992, Lo GiUdice et al. 1997, Pokorny et al. 2006). Furthermore, many studies of urban and suburban areas of England exist, with some of these studies repeated in different periods (PATON 1969, BAtes 1995, Porley 1996). DuCKetT and PRESSEL (2009) discussed the changes in the bryophyte diversity in the city of London in the last 150 years. Other ecological studies have shed light on the importance and peculiarity of bryophytes of urban areas (GILBERT 1968, 1970, 1989, Nickl-Navratil 1960, VARESChi 1936, Brandes 1983, Franzen 2001, Humer-Hochwimmer and Zechmeister 2001, Solga et al. 2006a, b, Solga and Frahm 2006, Sabovljević et al. 2005, 2007, Grdović and Stevanović 2006, Vukojević et al. 2005, 2006, FraHm and SABOVLJEvić 2007).

Urban and industrial areas are colonised by bryophytes, which are more or less resistant to high concentrations of toxic elements in the air, such as $\mathrm{SO}_{2}, \mathrm{SH}_{2}$, $\mathrm{NO}_{\mathrm{X}}$, etc. (Lo Giudice et al. 1997, Gilbert 1968).

BATES (1995) presented the bryoflora of Berkshire based on samples systematically collected since 1982, and data from earlier studies as well; in this paper 434 taxa are reported starting with very old reports (year 1660), but 55 of these taxa have not been found since 1980 or earlier. Distribution maps show distribution patterns affected by calcium carbonate content in the soil, rainfall changes, presence of areas with old trees, and atmospheric pollution as well. Comparison of the actual bryoflora with earlier studies shows significant decrease in the bryophyte frequency in different habitats, including epiphytic substrates. On the other hand, the frequency of at least 7 liverworts and 50 moss species increased. These changes may be attributed to several anthropogenic effects and pollutants. Atmospheric pollution has particularly caused biodiversity loss among epiphytes, but with the decrease of $\mathrm{SO}_{2}$ in recent decades several taxa have started to re-colonise lost territories of the past. For example, in another study (RICHTER et al. 2009) of the city of Halle (Germany) it is discussed that due the continuous decrease of atmospheric pollution re-colonisation of epiphytic bryophytes would start in "former deserts", the latter documented in previous studies (Müller 1993). HohenWAllner and Zechmeister (2001b) concluded that bryophytes in urban areas are sensitive to atmospheric pollution, but the latter is not the only factor; there are also other factors such as habitat changes and climate changes, particularly temperature and drought.

In Albania, bryological studies have been very scarce, mainly because of the lack of researchers (MARKA et al. 2012), and studies on urban bryofloras have not been carried out so far. In such conditions, and also inspired by the above cited literature sources, we are presenting in this paper the first attempt to contribute to the knowledge of the urban bryophyte flora in the city of Tirana. This 
study is aiming to give a general overview about epiphytic moss communities of trees in the main streets of Tirana's city centre and its adjacent Park. These data might serve as a database for future investigations in order to monitor the possible changes in epiphytic bryoflora, dynamics of these changes, and finally the causes and consequences.

\section{MATERIAL AND METHODS}

\section{Description of the investigated area}

The city of Tirana started to grow from its previous village state in the 18th century, but most of its urban development started after being appointed the capital of Albania in 1925. Tirana is situated in the central part of Albania, $110 \mathrm{~m}$ above see level, in a wide flat valley surrounded by Mt Dajti in the east direction, Kërraba and Sauku Hills in the south, Vaqarri and Yzberishti Hills in the west and Kamza Hills in the north. Its surface is $31 \mathrm{~km}^{2}$. Tirana, due to the influence of the Adriatic coast in the west, just at $34 \mathrm{~km}$ distance, has a typical Mediterranean climate. It has mild and humid winters and hot and dry summers. The mean temperatures are $7^{\circ} \mathrm{C}$ for January (minimum $-10.5^{\circ} \mathrm{C}$ ) and $24^{\circ} \mathrm{C}$ for July (maximum $41.5^{\circ} \mathrm{C}$ ). Temperatures below zero usually occur for 5-6 days per year, and it is quite rare that ice or snow lasts more than a day. Annual mean precipitation is estimated to $1189 \mathrm{~mm}$ as rain, from late autumn to early spring (KABO 1991).

Tirana has undergone several phases of urbanization, but particularly in the last 25 years it has been subjected to intensive urbanization, most of the time chaotic, which has caused severe damages to its green life, quality of social life and pollution. Thus, the number of inhabitants has grown considerably (almost tripled), construction of new buildings have caused the decrease of former green spaces, and the use of private cars has grown enormously, starting from a zero point in 1991. Today it is estimated that each day in Tirana circulate ca. 250,000 cars - most of which are second hand cars imported from EU countries - which have a high impact on pollution, particularly air pollution (AKM 2016).

Tirana, apart from the "Artificial Lake Park", due to its rapid and intensive urban development lacks big inward parks, or it used to have some modest parks, green patches, mainly in the city centre, or in the yards of small private villas, which however have been replaced by high buildings. Hence, the city's green life exists mainly on trees in pavements. But on the other hand only a few streets still have old trees, since most of the trees were planted in the last 15 years. The most common trees and shrubs on streets are Platanus orientalis, Tilia sp., Acer sp., Quercus ilex, Pinus sp., Ligustrum vulgare, Prunus sp., Nerium oleander, Magnolia grandiflora, etc. 
Tirana's Artificial Lake Park situated in the south of the city was built around the 1950s. The Park's surface is $1,522,000 \mathrm{~m}^{2}$, of which $365,000 \mathrm{~m}^{2}$ is the surface of the lake. The dominant trees of the Park are Robinia pseudoacacia, Quercus frainetto, Fraxinus excelsior, Cupressus sempervirens, Ligustrum lucidum, Pinus halepensis, Acer negundo, Cedrus atlantica, Eucalyptus camaldulensis, Nerium oleander, etc.

\section{Methods}

Altogether 145 trees - in 18 sampling points - were investigated for epiphytic mosses during the spring of 2016; 74 trees were sampled in the streets and green areas of the city, and 71 trees inside the Park's area (Fig. 1). Nomenclature of species follows HiLl et al. (2006). Several indices have been taken into account

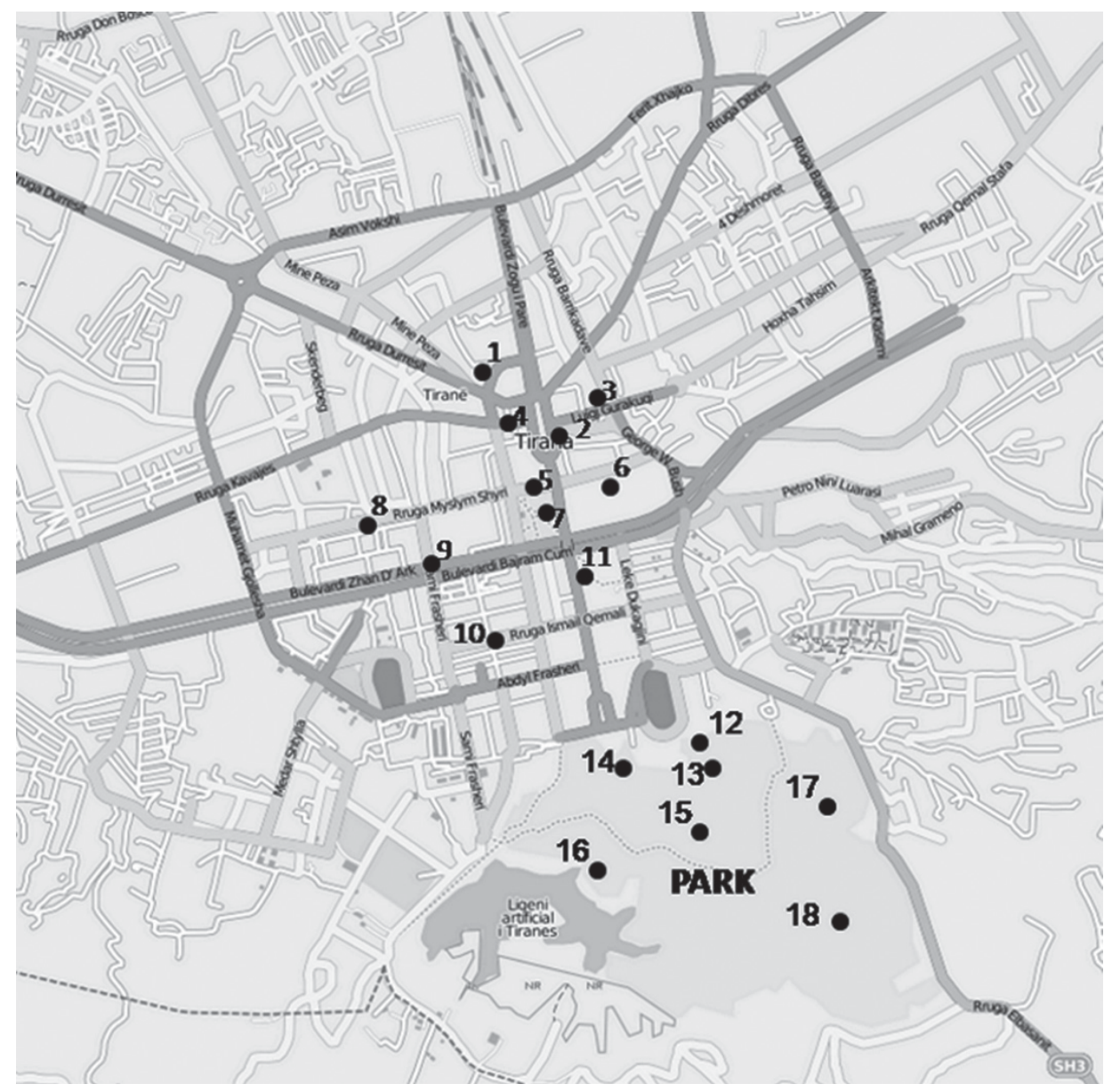

Fig. 1. Sampling points in the centre of Tirana city. 
for analyses, e.g. Shannon-Weaver ( $\left.\mathrm{H}^{\prime}\right)$ and Simpson index (D) for biodiversity and Sørensen’s Coefficient (CC) for community similarity (ANONYMous s. d.). Furthermore, indicator values of mosses (DÜLL 1991) were used for ecological discussions. Moss specimens are deposited in the author's collection at the Department of Biology (Tirana University, Tirana).

\section{RESULTS AND DISCUSSION}

We have divided the data of this study into two groups, the first group from the streets and small green areas of the city, which we named as "strictly urban" and the second one from the city's Park. Altogether 553 moss samples were collected from 145 tree trunks, resulting in a total of 40 moss taxa, 19 taxa for strictly urban area and 39 for Park area, with 18 taxa shared by both communities (Table 1).

Table 1. Number of trees, moss samples and number of species for each sampling area. $\mathrm{A}=$ Sampling area code according to map (see Figure 1); B = Number of trees sampled; C = Number of moss samples; $\mathrm{D}=$ Number of moss species; TSUA = Total for the strictly urban area; TPA = Total for the park area.

\begin{tabular}{cccc}
\hline A & B & C & D \\
\hline 1 & 5 & 12 & 5 \\
2 & 5 & 11 & 5 \\
3 & 1 & 2 & 2 \\
4 & 1 & 3 & 3 \\
5 & 2 & 6 & 5 \\
6 & 2 & 10 & 8 \\
7 & 7 & 26 & 10 \\
8 & 11 & 19 & 6 \\
9 & 18 & 51 & 12 \\
10 & 17 & 52 & 15 \\
11 & 4 & 10 & 7 \\
12 & 1 & 3 & 3 \\
TSUA & 74 & 205 & 19 \\
13 & 2 & 12 & 11 \\
14 & 10 & 51 & 20 \\
15 & 12 & 71 & 20 \\
16 & 19 & 87 & 16 \\
17 & 23 & 111 & 27 \\
18 & 5 & 16 & 13 \\
TPA & 71 & 348 & 39 \\
TOTAL & 145 & 553 & 40 \\
\hline
\end{tabular}




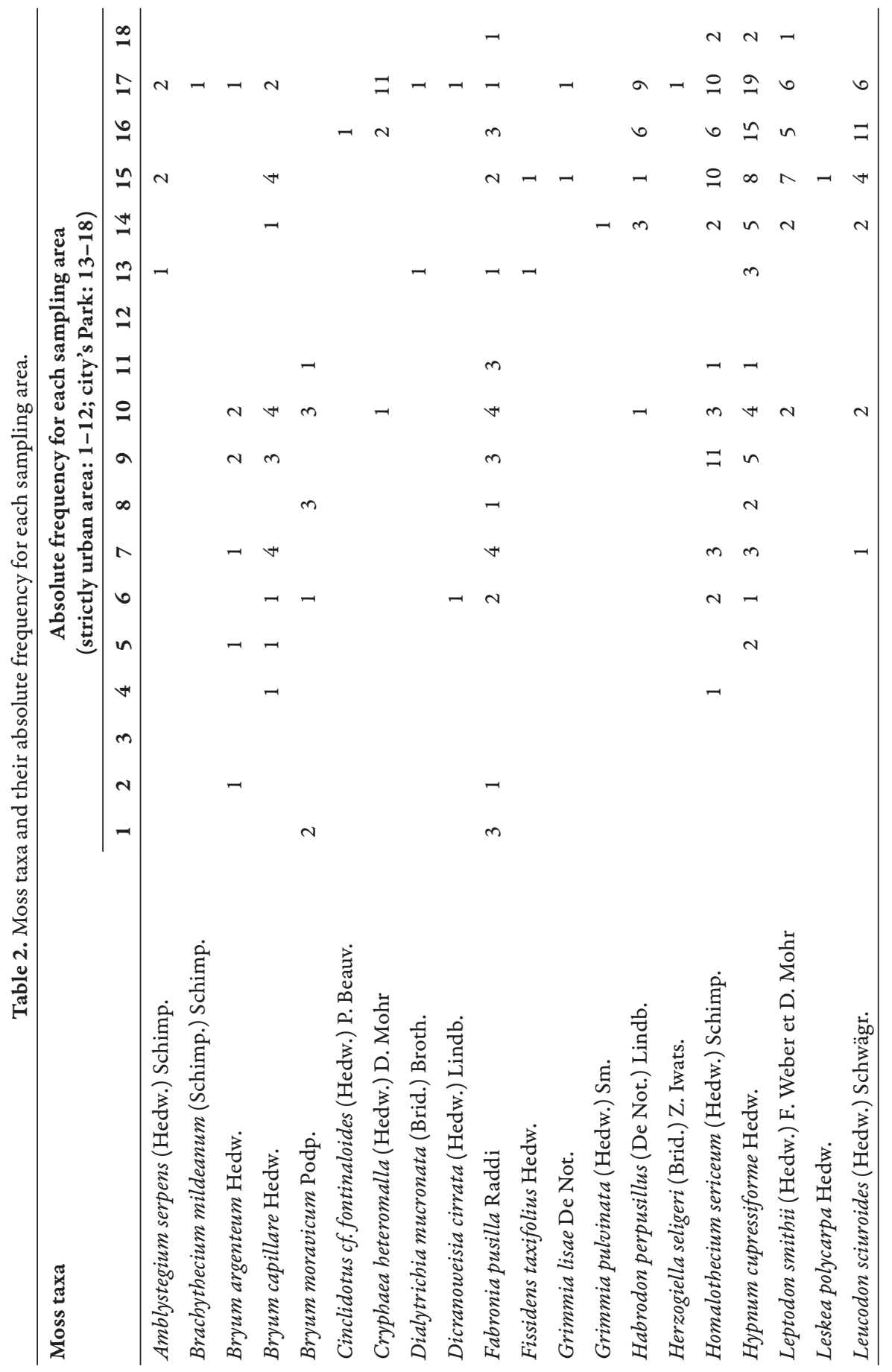

Studia bot. hung. 48(1), 2017 


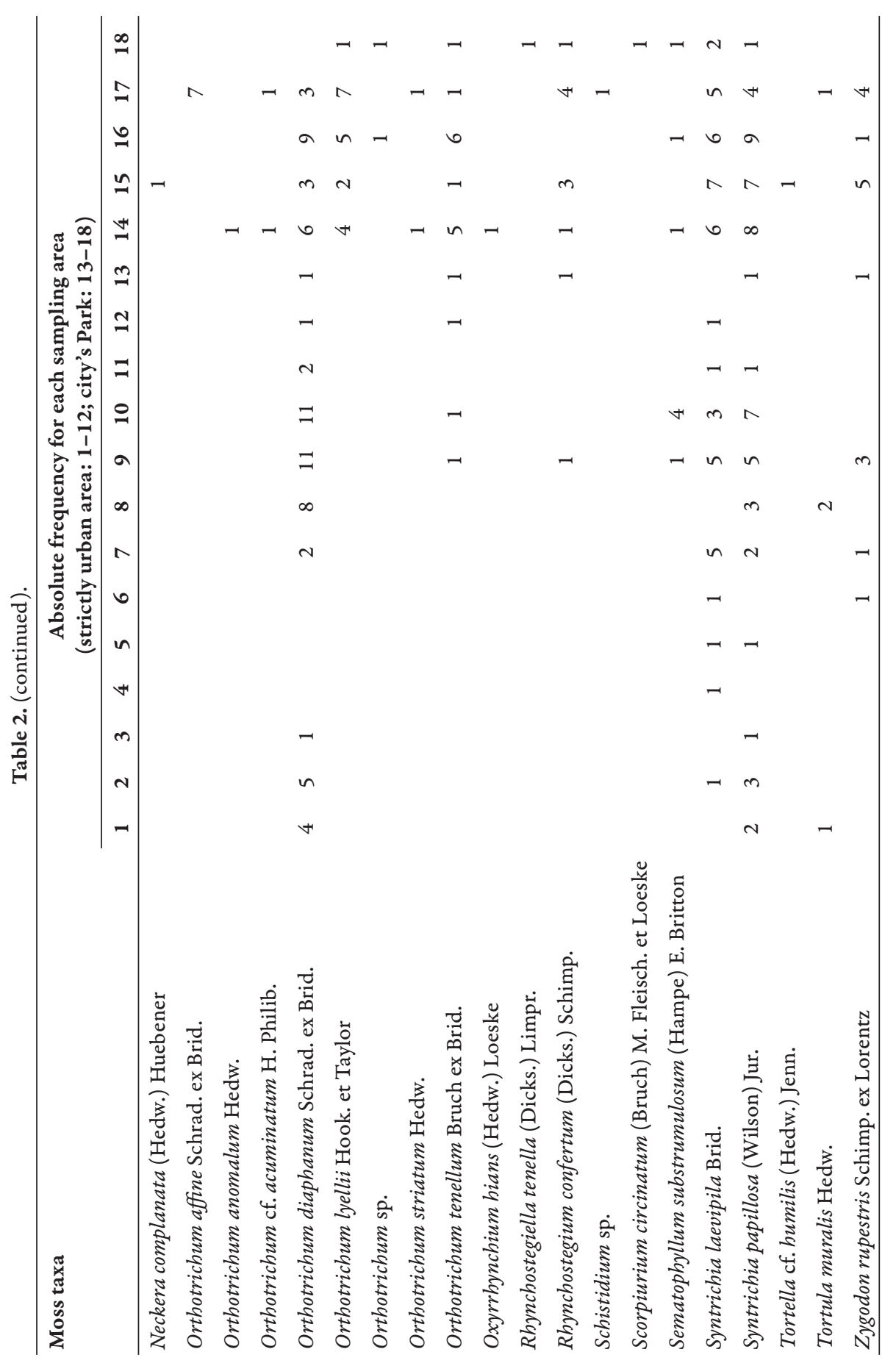


The full list of moss taxa recorded, including their absolute frequency, is given in Table 2. Furthermore, ranks of abundances are given for strictly urban and Park areas in Figures 2 and 3, respectively. For the strictly urban area the five most common species were Orthotrichum diaphanum, Syntrichia papillosa, Fabronia pusilla, Homalothecium sericeum and Syntrichia laevipila, with O. diaphanum, the only species having a frequency above $50 \%(61 \%)$. On the other hand, the five most common species of Park area are Hypnum cupressiforme, Homalothecium sericeum, Syntrichia papillosa, S. laevipila and Leucodon sciuroides, with $H$. cupressiforme the only species having a frequency above $50 \%$ (73\%). Comparing moss diversity of these two communities, different indices were calculated, Shannon (H) and Simpson (D) indices for diversity, and Sørensen (CC) coefficient for community similarities. These simple calculations are summarized in Table 3.

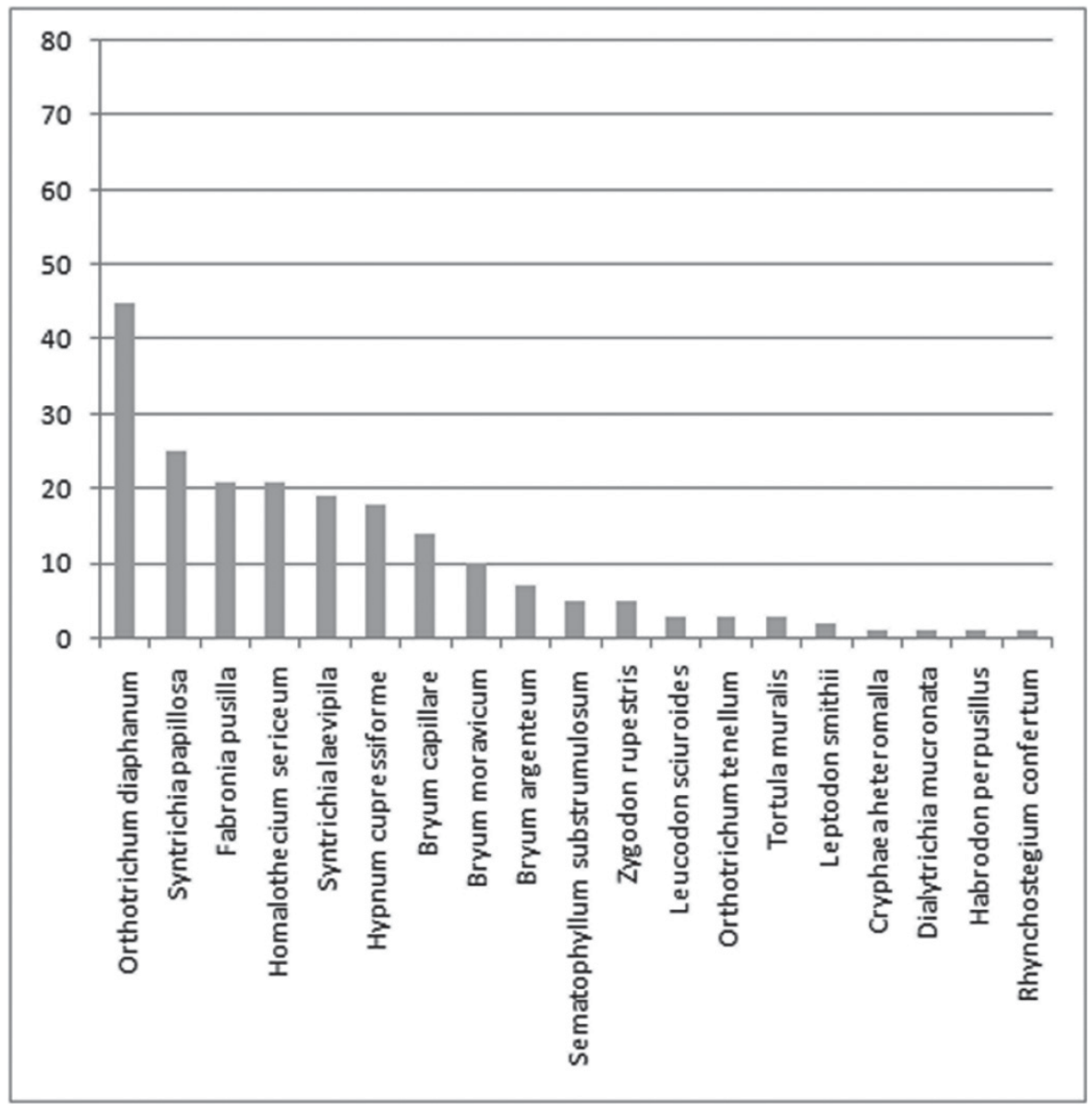

Fig. 2. Rank of species abundances for the strictly urban area. 


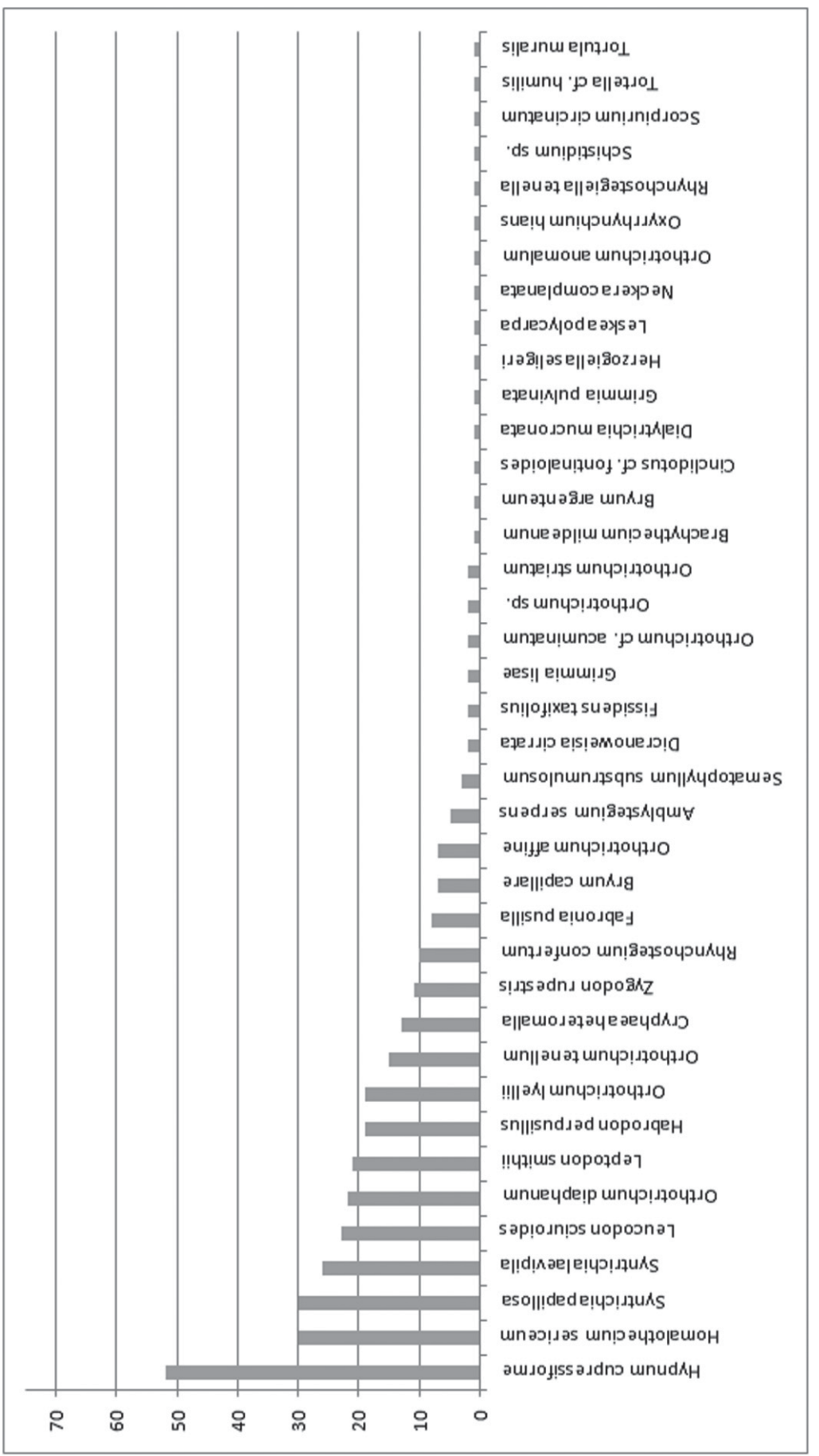

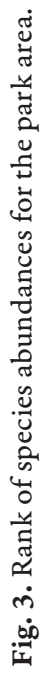


Table 3. Diversity indices and coefficient for community similarities.

\begin{tabular}{ccc}
\hline Biodiversity indices & Strictly Urban & Park \\
\hline Shannon (H) & 2.45 & 2.99 \\
Simpson (D) & 9.04 & 14.76 \\
\hline Similarity coefficient & & \\
Sørensen (CC) & 0.63 & \\
\hline
\end{tabular}

As it was empirically expected the values of biodiversity indices are higher for the Park area, and the similarity of these two communities is of average degree. The question may arise which are the causes of these differences in communities? Are these differences resulted mainly from microclimatic changes or other factors are contributing as well? As it has already been mentioned in the introduction this study may contribute only as a starting point of future investigations which may give more accurate answers. However, at this phase we have calculated the ecological values of moss species (DüLL 1991) for some parameters (light, temperature, humidity and reaction) to check if there are differences in the mean values of the two communities. Indeed, mean values of these ecological indices are slightly different in the two communities compared (Table 4).

For example, values for light, temperature and humidity confirm that in the strictly urban area the species dominates which prefer more light, higher temperature and drought than those of the Park's area. On the other hand the richness of an epiphytic moss community is also affected by $\mathrm{pH}$ and nutrition level of tree bark, where usually neutral and basic substrates (e.g. elders, elms, willows, etc.) shelter more species compared to acid ones (e.g. pines, birches, beeches, etc.) (VANDERPOORTEN and GofFINET 2009).

In Table 4 we see that the taxa growing in strictly urban area have a lower $\mathrm{pH}$ value than those of the Park's area. Is this ecological difference only related to the type of the host tree as discussed above, or it may also be influenced by air pollution which is known for increasing acidity through precipitation? Furthermore, recent reports from the National Environmental Agency show that levels of $\mathrm{SO}_{2}$ and $\mathrm{NO}_{2}$ for the year 2015 - compared to EU standards - are within the standards, although very close to the upper limit (AKM 2016). However, we do not know if these levels were within these EU standards for earlier periods.

Table 4. Average values for ecological indicators of mosses.

\begin{tabular}{lcccc}
\hline & \multicolumn{3}{c}{ Ecological indicators } \\
& Light & Temperature & Moisture & Reaction \\
\hline Average values for Park area & 6.6 & 5.2 & 4 & 6.4 \\
Average values for strictly urban area & 7 & 6 & 3.5 & 6 \\
\hline
\end{tabular}


From the floristic point of view the species recorded are all known in Albania. However, it is worth mentioning that Dicranoweisia cirrata is a confirmation of an old and single report from Shkodra (BAUMGARTNER 1915). Meanwhile, Fabronia pusilla was included in the preliminary red list of Albania (MARKA et al. 2012), and this was based indirectly on other regional red lists (NATCheva et al. 2006, ŞTEFĂNUȚ and Goia 2012), but these recent data suggest that this species has frequent occurrence in urban areas, and with abundant cover density, mostly in old Platanus trees. Another interesting record is Cryphaea heteromalla, which was recently reported for Albania (MARKA et al. 2013), and it is also red listed in Montenegro and Romania (SABOVLJEvić et al. 2004, ŞTEFĂNUȚ and GoIA 2012).

For many species that were recorded in our study some literature data are related to air quality, e.g. some species are reported as resistant to pollution and others are sensitive to it. Based on this, we can divide our species into several groups. For example, species which are widespread like Orthotrichum diaphanum, Syntrichia laevipila, Bryum capillare, Hypnum cupressiforme, Homalothecium sericeum, Rhynchostegium confertum, and other species which are less widespread like Amblystegium serpens and Dicranoweisia cirrata, but in literature these are mentioned as resistant to pollution (DUCKETT and PRESSEL 2009, GovindAPYARI et al. 2010). Another group of species are Cryphaea heteromalla, Habrodon perpusillus, Leucodon sciuroides, Syntrichia papillosa and Orthotrichum lyellii, which are reported as sensitive to air pollution (SMITH 2004, DUCKETT and PRESSEL 2009). In the third group there are species which based on their primary substrate are not epiphytic like Bryum argenteum, Tortula muralis, Grimmia pulvinata, Orthotrichum anomalum, Schistidum sp., and their presence on trees is explained with high level of dust in the air (DYMYTROVA 2009, FudALI 2012).

\section{CONCLUSIONS}

Among the epiphytic moss taxa recorded in Tirana's city centre some are known as resistant to air pollution and others are sensitive to it. Furthermore, the data show differences in epiphytic moss communities when the strictly urban area is compared with the Park's area. Are these differences only a consequence of microclimatic conditions, or other factors - like air pollution - might influence it? At present, this remains an open question as the long term monitoring of biodiversity dynamics will be needed on the one hand and a standardized method to check for correlations between biological parameters and chemicalphysical parameters on the other hand. 
Acknowledgements - We are thankful to the anonymous reviewers for their comments, suggestions and for the improvement of English as well.

Összefoglaló: Tanulmányunk áttekintést nyújt a fán lakó mohaközösségek összetételéről Tirana (Albánia) belvárosában és a közeli parkban. 2016 tavaszán összesen 145 fát vizsgáltunk meg és 553 mohamintát gyüjtöttünk, melyek 40 fajhoz tartoznak. Közülük 19 fordul elő a belvárosi környezetben és 39 a vizsgált parkban; 18 faj közös a két terület mohaflórájában. A belvárosi területen az öt leggyakoribb mohafaj az Orthotrichum diaphanum, Syntrichia papillosa, Fabronia pusilla, Homalothecium sericeum és a Syntrichia laevipila; a parkban pedig a Hypnum cupressiforme, Homalothecium sericeum, Syntrichia papillosa, S. laevipila és Leucodon sciuroides. A diverzitási indexek a parkban magasabbnak mutatkoztak. A kimutatott mohák közül egyesek jól türik a légszenynyezést, mások érzékenyek rá. A fajok ökológiai mutatói alapján megállapítottuk, hogy a belvárosi környezetben a fény- és hőigényesebb, szárazságtürő fajok domináltak a parkkal szemben és ugyanitt az alacsonyabb $\mathrm{pH}$-értékeket igénylő fajok aránya nagyobb. Annak megválaszolása, hogy a két terület között kimutatott mohaflórabeli különbségek kizárólag azok mikroklimatikus különbségeire vagy egyéb okokra is visszavezethetők, további vizsgálatokat igényel. A vizsgálataink során kimutatott Dicranoweisia cirrata a faj egyetlen régi, Shkodrából származó albániai adatának megerősítése, míg a Fabronia pusilla szerepel Albánia előzetes moha-vöröslistájában.

\section{REFERENCES}

AKM (2016): Raporti i Gjendjes në Mjedis 2015. - Agj. Komb. e Mjedisit, Tiranë: A \& D, pp. 1-256. AlefFi, M. (1991): Bryophyte flora and air quality in the town of Jesi (Marche, Central Italy). Arch. Bot. Ital. 67: 128-140.

Aleffi, M. and Taruschio, E. (1996): Bryophyte flora and airquality in the town of Treia (Marche, Central Italy). - Arch. Geobot. 2: 47-58.

Anonymous (s.d.): How to calculate biodiversity. - http://entnemdept.ifas.ufl.edu/hodges/ ProtectUs/lp_webfolder/9_12_grade/Student_Handout_1A.pdf (accessed: 21.04.2017)

Ballesteros Segura, T. and Ron, M. E. (1985): Contributionto bryophyte flora of the city of Toledo. - Anales Jard. Bot. 42: 87-91.

Bates, J. W. (1995): A bryophyte flora of Berkshire. - J. Bryol. 18(3): 503-620. http://dx.doi.org/10.1179/jbr.1995.18.3.503

Baumgartner, J. (1915): Verzeichnis der von I. Dörfler auf seiner Reise im albanisch-montenegrinischen Grenzgebiete im Jahre 1914 gesammelten Moose. - Österr. Bot. Zeitschr. 65(10-12): 312-319. https://doi.org/10.1007/bf01661000

Benkert, D., Erzberger, P., Klawitter, J., Linder, W., Linke, C., Schaepe, A., Steinland, M. and WieHLE, W. (1995): The moss list of Brandenburg and Berlin including the threat levels. - Verh. Bot. 128: 1-68.

Bento-Pereira, F., and Sergio, C. (1983): Lichens and bryophytes as bioindicators of atmospheric pollution. - Rev. Biologia 12: 297-313.

Brandes, D. (1983): Flora und Vegetation der Bahnhöfe Mitteleuropas. - Phytocoenologia 11: 31 115. https://doi.org/10.1127/phyto/11/1983/31

CARCANo, L. (1989): Moss inventory of the urban area of Rome (Italy). - Braun Blanquetia 3: $147-150$.

CaSAs, C. and SAIZ, C. (1982): The bryophytes of the cathedral of Sevilla. - Collect. Bot. 13: 163-175. 
Cortini Pedrotti, C. (1989): Bryophyte flora of the Camerino town (Central Italy). - Braun Blanquetia 3: 75-86.

DiA, M. G. and Not, R. (1991): Gli agenti biodeteriogeni degli edifici monumentali del centro storico della città di Palermo. - Quad. Bot. Ambientale Appl. 2: 3-10.

Duckett, J. and Pressel, S. (2009): The changing bryoflora of London. - Field Bryol. 98: 30-45.

DüLL, R. (1991): Indicator values of mosses and liverworts. - In: EllenberG, H., Weber, H. E., Düll, R., Wirth, V., Wemer, W. and Paulissen, D. (eds): Indicator values of plants in Central Europe. Erich Goltze, Göttingen, pp. 175-214.

Dymytrova, L. (2009): Epiphytic lichens and bryophytes as indicators of air pollution in Kyiv city (Ukraine). - Folia Cryptog. Estonica 46: 33-44.

Esteve, F., VAro, J. and Zafra, M. L. (1977): Bryological studies of the Granada city. - Trab. Dep. Bot. Univ. Granada 4: 45-71.

Fiol, A. (1983): Bryophytes of urban habitats of Palma de Mallorca. - Bol. Soc. Hist. Nat. Balears 27: 65-76.

Frahm, J. P. and SABovljević, M. (2007): Reduction of microdust by mosses. - Immissionsschutz 4: $152-156$.

FRANZEN, I. (2001): Epiphytic mosses and lichens as bioindicators of air quality in west edge of Ruhr Region. - Limprichtia 16: 1-23.

FUDALI, E. (2012): Recent tendencies in distribution of epiphytic bryophytes in urban areas. Polish Bot.J. 57(1): 231-241.

Gilbert, O. L. (1968): Bryophytes as indicators of air pollution in the Tyne Valley. - New Phytol. 67: 15-30. https://doi.org/10.1111/j.1469-8137.1968.tb05450.x

Gilbert, O. L. (1970): Urban bryophyte communities in North-East England. - Trans. Br. Bryol. Soc. 6: 306-316. https://doi.org/10.1179/006813871804146373

Gilbert, O. L. (1989): The ecology of urban habitats. - Chapman and Hall, London, 369 pp.

Govindapyari, H., Leleeka, M., Nivedita, M. and Uniyal P. L. (2010): Bryophytes: indicators and monitoring agents of pollution. - NeBIO 1(1): 35-41.

Grdović, S. and Stevanovic, V. (2006): The moss flora of central urban area of Belgrade. - Arch. Biol. Sci. 58: 55-59. https://doi.org/10.2298/abs0601055g

Heras, P. and Soria, A. (1990): Urban mosses and hepatics of the city of Vitoria-Gasteiz. - Soc. Est. Vascos, Secc. Ci. Nat. 7: 75-116.

Hill, M. O., Bell, N., Bruggemann-Nannenga, M. A., Brugués, M., Cano, M. J., Enroth, J., Flatberg, K. I., Frahm, J.-P., Gallego, M. T., Garilleti, R., Guerra, J., Hedenäs, L., Holyoak, D. T., Hyvönen, J., Ignatov, M. S., Lara, F., Mazimpaka, V., Muñoz, J. and SÖDERSTRÖM, L. (2006): An annotated checklist of the mosses of Europe and Macaronesia. - J. Bryol 28: 198-267. https://doi.org/10.1179/174328206x119998

Hohenwallner, D. and Zechmeister, H. G. (2001a): Noteworthy moss records in the Vienna downtown. - Linzer Biol. Beitr. 33: 295-298.

Hohenwallner, D. (2000a): Bioindication with mosses in city area of Vienna. - Limprichtia 15: $1-88$.

Hohenwallner, D. (2000b): Viennas' Chinese Wall. - Derive 1: 15.

Hohenwallner, D. and Zechmeister, H. G. (2001b): Factors influencing bryophyte species richness and populations in urban environments: A case study. - Nova Hedwigia 73: 87-96.

Humer-Hochwimmer, K. and Zechmeister, H. G. (2001): Epiphytic mosses in Vienna forest within the city of Vienna and its significance for bioindication of atmospheric pollutants. Limprichtia 18: 1-99.

Каво, M. (1991): Gjeografia fizike e Shqipërisë (Vëllimi II). - Akademia e Shkencave, Qendra e Studimeve Gjeografike, Tiranë, 592 pp. 
Lara, F., Lopez, C. and Mazimpaka, V. (1991): Bryophyte ecology in the town of Segovia, Spain. - Cryptogamie, Bryol. Lichenol. 12: 425-439.

LARA, F. and Mazimpa Ka, V. (1989): Contribution to the bryophyte flora of the city of Segovia. Anales Jard. Bot. 46: 481-485.

Lo GIUdiCE, R. (1992): Contribution to the urban bryophyteflora of Catania. - 2uad. Bot. Ambientale Appl. 3: 3-10.

Lo Giudice, R., Mazimpaka, V. and Lara, F. (1997): The urban bryophyte flora of the city of Enna (Sicily, Italy). - Nova Hedwigia 64: 249-265.

Marka, J., Papp, B., Erzberger, P., Sabovljević, M. and Colacino, C. (2012): Towards a red list of the Albanian bryophytes. - Studia bot. hung. 43: 13-25.

Marka, J., Erzberger, P. and PApp, B. (2013): New and interesting moss records from Albania. - J. Bryol. 35: 152-155.

MazimpaKa, V. (2006): The bryophyte flora of the city of Trento (North Italy). - Vicente Mazimpaka Academia. edu.: 265-284.

Mazimpaka, V., Vicente, J. and Ron E. (1988): Contribution to the urban bryophyte flora of the city of Madrid. - Anales Jard. Bot. 45: 61-73.

Mazimpaka, V., Lara, F. and Lopez-Garcia, C. (1993): Ecological data on the bryophyte flora of the town of Cuenca (Spain). - Nova Hedwigia 56: 113-129.

MülleR F. (1993): Studien zur Moss- und Flechtenflora der Stadt Halle/S. - Limprichtia 1: 1-16.

Natcheva, R., Ganeva, A. and Spiridonos, G. (2006): Red list of the bryophytes in Bulgaria. Phytol. Balcan. 12(1): 55-62.

Nickl-Navratil, H. (1960): Small moss communities of towns. - Nova Hedwigia 2: 425-462.

Paton J.A. (1969): A bryophyte flora of Cornwall. - Trans. Br. Bryol. Soc. 5(4): 669-756. https://doi.org/10.1179/006813869804146646

Pokorny, L., Lara, F. and Mazimpaka, V. (2006): The bryophyte flora of the city of Trento (North Italy) -Cryptogamie Bryol. 27: 265-284.

Porley, R. D. (1996): Further observations on the bryophytes in Chawley Brick Pit, Oxford - J. Bryol. 19(1): 185-187. https://doi.org/10.1179/jbr.1996.19.1.185

Rams, S., Ros, R. M., CANo, M. S. and Guerra, J. (2000): Urban bryophyte flora of the city of Murcia. - Bol. Soc. Esp. Briol. 7: 9-18.

RiChter, S., SCHUÜTZE, P. and BRUelHeIde, H. (2009): Modelling epiphytic bryophyte vegetation in an urban landscape. - J. Bryol. 31: 159-168. https://doi.org/10.1179/174328209x431277

Ron, E., Mazimpaka, V., Vicente, J. and Granzow de la Cerda, I. (1987): Urban bryophytes in Spanish towns. - Symp. Biol. Hung. 35: 727-753.

Sabovljević, M., Cvetić, T. and Stevanović, V. (2004): Bryophyte red list of Serbia and Montenegro. - Biodiversity and Conservation 13: 1781-1790. https://doi.org/10.1023/b:bioc.0000029338.97776.66

SABOVLJEVIĆ, M. and GRDović, S. (2009): Bryophyte Diversity within urban Areas: Case Study of the city of Belgrade (Serbia). - Int. J. Bot. 5(1): 85-92.

Sabovljević, M., Vukojevic, V., Mihailović, N., Dragić, G. and Vueinić, Z. (2005): Determination of heavy metal deposition in the county of Obrenovac (Serbia) using mosses as bioindicators. I: Aluminium (Al), Arsenic (As) and Boron (B). - Arch. Biol. Sci. 57: 205-212. https://doi.org/10.2298/abs0503205s

Sabovljević, M., Vukojevic, V., Sabovljević, A., Mihailovic, N., Dragić, G. and Vueinić, Z. (2007): Determination of heavy metal deposition in the county of Obrenovac (Serbia) using mosses as bioindicators III. Copper (Cu), Iron (Fe) and Mercury (Hg). - Arch. Biol. Sci. 59: 351-361. https://doi.org/10.2298/abs0704351s

SCHAEPE, A. (1986): Changes of the mossflora of Berlin (west). - Bryophyt. Bibl. 33: 1-392. 
SERGIO, C. (1981): Changes in epiphytic bryophyte flora in urban area of Lisbon in last 140 years. - Bol. Soc. Brot. Ser. 2: 291-303.

Sergio, C. and Bento-Pereira, F. (1981): Lichens and bryophytes as bioindicators of atmospheric pollution. I. - Bol. Soc. Brot. Ser. 2: 313-331.

Smit H, A. J. E. (2004): The moss flora of Britain and Ireland. 2nd ed. - Cambridge University Press, Cambridge, 1026 pp. https://doi.org/10.1017/cbo9780511541858

Solga, A. and Frahm, J. P. (2006): Nitrogen accumulation of six pleurocarpous moss species and their suitability for monitoring nitrogen deposition. - J. Bryol. 28: 46-52. https://doi.org/10.1179/174328206x104552

Solga, A., Eichert, T. and Frahm, J. P. (2006a): Historical alteration in the nitrogen content and $15 \mathrm{~N}$ natural abundance of mosses in western Germany: Indication for regionally varying changes in atmospheric nitrogen deposition within the last 140 years. - Atmos. Environ. 40: 8044-8055. https://doi.org/10.1016/j.atmosenv.2006.03.024

Solga, A., BURKhARDT, J. and Frahm, J. P. (2006b): A new approach to assess atmospheric nitrogen deposition by way of standardized exposition of mosses. - Environ. Monit. Assess. 116: 399-417. https://doi.org/10.1007/s10661-006-7659-5

SoriA, A. and Ron, M. E. (1990): Contribution to the urban bryophyte flora of the city of Logrono. - Anales Jard. Bot. 46: 427-432.

SoriA, A. and Ron, M. E. (1995): Contributions to the Spanish urban bryophyte flora. - Cryptogamie Bryol. Lichenol. 16: 285-299.

Soria, A., Ron, M. E. and Heras, P. (1992): Comparative analysis of the urban bryoflora of Vitoria-Gasteiz with the others Spanish cities. - Actes Simposi Intemac. Bot. Pius Font I. Quer., pp. 271-276.

ŞTEFĂnUȚ, S. and GoiA, I. (2012): Checklist and red list of bryophytes of Romania. - Nova Hedwigia 95(1-2): 59-104. https://doi.org/10.1127/0029-5035/2012/0044

VANDERPoorten, A. (1997): A bryological survey of the Brussels capital region (Belgium). Scripta Botanica Belgica 14: 1-40.

VANDERPOORTEN, A. and GofFinet, B. (2009): Introduction to bryophytes. - Cambridge University Press, Cambridge, 303 pp. https://doi.org/10.1017/cbo9780511626838

VARESCHI, V. (1936): Epiphytic vegetation of Zurich. - Ber. Schweiz. Bot. Ges. 46: 445-488.

Vicente, J., De La Cerda, I. G., Mazimpaka, V. and Ron, M. E. (1986): Contribution to the urban bryoflora of the city of Avila. - Trab. Dep. Bot. 13: 45-49.

Vukojević, V., Sabovljević, M. and Jovanović, S. (2005): Mosses accumulate heavy metals from the substracta of coal ash. - Arch. Biol. Sci. 57: 101-106.

Vukojević, V., Sabovljević, M., Sabovljević, A., Mihailović, N., Dragić, G. and Vueinić Z. (2006): Determination of heavy metal deposition in the county of Obrenovac (Serbia) using mosses as bioindicators II: Cadmium (Cd), Cobalt (Co) and Chromium (Cr). - Arch. Biol. Sci. 58: 95-104.

Zechmeister, H. G., Hohenwallner, D. and Humer-Hochwimmer, K. (2001). The researches of the moss flora of Vienna. - Berichte der Reinhold-Taxen-Gesellschaft 13: 291-295.

(submitted: 12.04.2017, accepted: 11.05.2017) 